$\begin{array}{r}\text { Phinisi Integration Review } \\ \text { Vol. 2, No.1, Februari 2019 Hal 001-008 } \\ \text { Website: http://ojs.unm.ac.id/pir } \\ \text { p-ISSN: 2614-2325 dan e-ISSN: 2614-2317 } \\ \hline\end{array}$

\title{
Penguasaan Reproduksi Ruang Di Kawasan Bandar Udara Internasional Sultan Hasanuddin
}

\author{
Adi Sumandiyar ${ }^{(1)}$, Hasruddin Nur ${ }^{(2)}$ \\ Dosen Sosiologi Fisipol Universitas Sawerigading Makassar \\ email: adisumandiyar@gmail.com
}

\begin{abstract}
Abstrak. Jenis penelitian adalah kualitatif dengan menggunakan pendekatan konstruktivisme, yakni memahami (verstehen) proses makna dan efek dari penguasaan reproduksi ruang. Dalam pengumpulan datanya, peneliti mengumpulkan data wawancara dimana peneliti bertindak selaku instrumen penelitian. Hasil penelitian menunjukkan bahwa penduduk lokal hampir sebagian besarnya telah mengadopsi trend yang dilakukan oleh penduduk pendatang (warga masyarakat kota). Hal tersebut dapat dilihat dari perkembangan yang terjadi dalam kehidupan warga masyarakat lokal yang cenderung mengalami perubahan. Penguasaan reproduksi ruang tidak hanya berasal dari bagian yang lebih jauh dari lahan kekotaan terbangun saja, namun banyak juga yang datang dari bagian dalam kota. Sebab-sebab tertentu tersebut merupakan kekuatan-kekuatan penentu penyebab terjadinya mobilitas tempat tinggal (residential mobility) dan mobilitas fungsifungsi (functional mobility).
\end{abstract}

Kata Kunci: Penguasaan Reproduksi Ruang; Kawasan Bandar Udara Internasional Sultan Hasanuddin.

\begin{abstract}
This type of research is qualitative by using a constructivism approach, namely (verstehen) the process of meaning and effects of mastery of reproduction of space. In collecting the data, the researcher collected interview data where the researcher acted as the research instrument. The results of the study show that most of the local population has adopted a trend carried out by immigrants (urban residents). This can be seen from the developments that occur in the lives of residents of local communities who tend to experience changes. Mastery of reproduction of space does not only come from a part that is further away from the built up urban land, but many also come from the inner part of the city. Certain causes are the determinants of the causes of residential mobility and functional mobility.
\end{abstract}

Keywords: Mastery of Reproductive Space; Sultan Hasanuddin International Airport Area. 


\section{PENDAHULUAN}

Beranjak dari kajian studi perkotaan yang fokusnya menggunakan pendekatan sosiospasial dielaborasi melalui karya Henri Lefebvre (1991), David Harvey (1990, 2003, 2012), dan Castells, Manuel (1977). Mereka mengeksplorasi ruang dari perspektif Marxian. Dari perspektif ruang, adanya fenomena kontestasi, negosiasi, konsensus, dan konflik diperkotaan dapat dipahami sebagai bentuk relasi kuasa dari aktor-aktor penataan ruang yang meliputi pemerintah, masyarakat, dan pasar. Relasi tiga aktor ini memengaruhi praktik tata ruang. Pendekatan sosio-spasial memandang bahwa keterlibatan pemerintah dengan kepentingan serta kemauan politiknya sebagai cara memacu pertumbuhan dan sekaligus sebagai instrumen perubahan kota yang mengacu pada pembangunan global metropolitan.

Perubahan-perubahan tata ruang di perkotaan yang memiliki karakteristik sebagai kota industri modern dan memengaruhi setiap warga serta kehadiran investor atau pengembang yang melakukan pembangunan gedung, fasilitas umum, ruang publik, dan lainnya merupakan bentuk investasi yang terkait dengan perubahan dan tuntutan ekonomi global. Perubahanperubahan tata ruang di perkotaan dapat memberikan pemahaman mengenai sinergi pemerintah lokal (Kabupaten Maros dan Kota Makassar) dan pemerintah nasional (pusat) dengan kekuatan kapital (nasional dan internasional) dalam mengembangkan kawasan industri, real estate, Bandar Udara Internasional Sultan Hasanuddin di Kabupaten Maros Kota Makassar dan sebagainya.

Pemahaman mengenai praktik tata ruang, khususnya dalam pembuatan Rencana Tata Ruang dan Wilayah (RTRW) suatu kota, dapat dilihat dengan cara bagaimana ruang-ruang itu dikonstruksi dan diperebutkan oleh tiap-tiap aktor berdasarkan kepentingannya yang diwujudkan dalam pendirian bangunan, jaringan transportasi, taman, ruang terbuka hijau, dan sebagainya. Proses mengonstruksi ruang itu erat kaitannya dengan relasi kuasa antar aktor yang berada dalam tarikan pendulum dan kontinuitas konflik-kontestasi. Penelitian ini menjelaskan bahwa ruang adalah sebuah area dan alat yang berfungsi melestarikan tatanan ekonomi-politik. Ruang itu memiliki karakteristik interaktif dari investor/kapitalis (pengusaha), negara (pemerintah), dan masyarakat (termasuk lembaga swadaya masyarakat yang memiliki kepedulian di bidang ekologi). Oleh sebab itu, konflik dan kontestasi antar aktor dalam praktik tata ruang tidak bisa dihindari.

Ruang sebagai produk politik mengakibatkan praktik tata ruang tidak pernah bebas dari keberpihakan aktor yang membuat regulasi tata ruang. Keberpihakan atau ketidaknetralan aktor-aktor dalam menjalankan kuasanya tercermin dari kebijakan yang dibuat oleh regulator (pemerintah). Praktik penataan ruang meliputi kegiatan produksi dan reproduksi ruang yang di dalamnya terdapat perjuangan dari kelas-kelas untuk mendapatkan dan menguasai ruang itu (Lefebvre 1974, 1991). Bandar Udara Internasional Sultan Hasanuddin mengalami proses perluasan dan pengembangan yang dimulai tahun 2004 dan direncanakan selesai pada tahun 2009. Antara bagian dari pengembangan adalah terminal penumpang baru berkapasitas 7 juta penumpang per tahun, apron (lapangan parkir pesawat) yang berkapasitas tujuh pesawat berbadan lebar, landas pacu baru sepanjang 3.100 meter $\mathrm{x} 45$ meter, serta taxiway. Pengoperasian terminal baru dimulai pada 4 Agustus 2008 dengan menggunakan landas pacu lama karena landas pacu baru masih sedang dikerjakan. Sekarang, Bandar Udara Internasional Sultan Hasanuddin Sudah Mengoperasikan Apron baru, landas pacu terbaru serta 1 buah taxiway. Perpanjangan landasan tahap 2 dari 3,100 meter menjadi 3,500 meter akan mulai dilaksanakan antara akhir tahun 2011 atau awal 2012, setelah pembebasan lahan terlaksanakan. Perpanjangan landasan ini ditujukan agar kedepannya dapat didarati pesawat berbadan lebar seperti Boeing 747 secara maksimal. Dari pembebasan lahan ini memicu terjadinya penguasaan reproduksi ruang yang dilakukan oleh para pengambil kebijakan.

Dalam hal ini Lefebvre, 1991, menegaskan bahwa berbagai perbedaan fenomena perjuangan kelas atas suatu ruang itu terkait dengan suatu daerah, kawasan, wilayah, situs, tanah, dan sebagainya, dan hal ini harus dipahami sebagai bagian dari proses spasialisasi yang sama. Proses spasialisasi itu merupakan paduan dari tiga unsur. Pertama, praktik spasial yang terkait dengan rutinitas individu untuk penciptaan sistematis zona dan wilayah. Praktik tata ruang tersebut dari waktu ke waktu diwujudkan dalam lingkungan dan lanskap yang tertata. Praktik 
spasial yang paling signifikan diperkotaan terkait dengan pembangunan sektor propertidan bentuk-bentuk operasional kapital lainnya. Kedua, adanya representasi ruang, bentukbentuk pengetahuan, dan praktik-praktik yang mengatur dan mewakili ruang terutama melalui teknik perencanaan dan keterlibatan negara (pemerintah). Ketiga, adanya pengalaman kolektif ruang. Hal ini terkait dengan ruangruang representasi yang dialami setiap orang. Pada konteks ini pasar membangun sistem untuk penciptaan dan akumulasi keuntungan. Dengan demikian maka pertanyaan penelitian adalah bagaimana penguasaan reproduksi ruang di sekitar kawasan Bandar Udara Internasional Sultan Hasanuddin?

\section{METODE PENELITIAN}

Jenis penelitian adalah kualitatif dengan menggunakan pendekatan konstruktivisme. Dalam pengumpulan datanya, penulis mengumpulkan data dengan cara bertindak selaku instrumen penelitian. Data dikumpulkan penguasaan reproduksi ruang di sekitar kawasan Bandar Udara Internasional Sultan Hasanuddin. Data tersebut diperoleh melalui dua sumber data, yakni; dokumentasi dan informan. Teknik pengumpulan datanya dilakukan melalui metode wawancara mendalam. Data tersebut selanjutnya dianalisis dengan menggunakan teknik analisis deskriptif dimaksudkan untuk melihat proses, makna, dan dinamika sosial orang manggarai.

Lokasi penelitian terletak di Kota Makassar Provinsi Sulawesi Selatan Indonesia. Adapun informan dalam penelitian ini sebanyak 15 Orang yang dipilih dengan cara purposive random sampling. Jenis data penelitian yang diperlukan adalah data primer dan data sekunder berupa praktik non-diskursif (peristiwa interaksi sosial, dan dinamika sosial).

Tahapan pengumpulan dan analisis data mengikuti alur siklus, interaktif, dan berlangsung secara terus-menerus sampai tuntas, sehingga data menjadi jenuh. Konsep tersebut meliputi data reduction, data display, dan conclusion: drawing/verifying.

\section{HASIL DAN PEMBAHASAN}

\subsection{Struktur sosial}

Struktur sosial yang berada di kawasan bandara terebut kini telah berubah akibat dari penguasaan ruang yang diproduksi oleh pengelola bandara. Penguasaan ruang yang terjadi dimanfaatkan oleh oknum-oknum pengelola bandara untuk menjadikan lahan tersebut sebagai lahan keuntungan mereka dengan cara membiarkan warga masyarakat menghgarap lahan dari bandara, namun pada akhirnya oknum pengelola bandara meminta agar hasil yang diperoleh dari pengelolaan lahan juga sebagian diserahkan oleh oknum yang mengatasnamakan bandara. Fenomena tersebut mencerminkan bahwa lahan yang telah dikuasai oleh pengelola bandara telah terjadi praktik kapitalisasi ruang yang mengarah kepada keuntungan dari hasil yang diperoleh oleh warga nasyarakat lokal, sehingga warga masyarakat hanya dijadikan sebagai alat untuk memperoleh keuntungan yang sebesar-besarnya.

Struktur sosial lainnya adalah terdapatnya perubahan harga lahan yang tidak sesuai dan dianggap banyak memberikan kerugian bagi warga masyarakat, sehingga dalam proses pemnbayarannya, masih terdapatnya kerugian yang terjadi dalam proses pembayaran. Masyarakat juga seringkali diajak untuk menentukan harga, namun pada faktanya harga yang mereka terima tidak sesuai dengan kesepakatan diawal pembicaraan, sehingga mengakibatkan perubahan kepercayaan yang dialami oleh warga masyarakat lokal serta yang memiliki lahan untuk tidak sepenuhnya menaruh harapan kepercayaan kepada pengelola bandara. Hal lain yang perlu disoroti terkait dengan harga lahan adalah aktor yang berperan dalam transaksi jual beli lahan di Kawasan Bandar Udara Internasional Sultan Hasanuddin. Dalam hal ini Kawasan Bandar Udara Internasional Sultan Hasanuddin berada pada Wilayah Peri Urban (WPU). Dimana penduduk merupakan agen yang menjadi penyebab terjadinya transformasi spasial di WPU, namun demikian penduduk pula yang akan mengalami dampak dari adanya tranformasi spasial ini khususnya mengenai harga lahan yang terjadi. Berdasarkan peranannya dalam hal jual beli lahan di WPU dikenal ada 3 aktor kunci, yaitu; (1) pemilik lahan awal sebelum ada pembangunan (pradevelopment lands owners); (2) pihak perantara (intermediate actors); dan (3) konsumen akhir (final consumers).

Para pengembang memilih lahan belum terbangun yang memiliki harga lahan yang sangat rendah disebabkan beberapa faktor, 
antara lain; aksesibilitas yang sangat rendah, kualitas lahan yang sangat rendah untuk pertanian sehingga harga lahan ditentukan atas dasar agricultural based value. Namun begitu lahan tersebut dikembangkan menjadi sebuah kompleks perumahan, maka lahan yang sudah menjadi kompleks perumahan yang sudah teratur, nyaman dengan aksesibilitas yang tinggi, maka pengembang akan menentukan harga lahannya berdasarkan urban based value yang dibebankan pada harga jualnya. Sementara peran lembaga keungan berperan memberikan fasilitas kredit bagi mereka yang berminat meminjam uang untuk membeli lahan yang kemudian membangunnya. Ketiga, konsumen akhir, pengguna akhir/konsumen akhir dapat terdiri dari berbagai aktor juga dimulai dari perorangan, kelompok maupun lembaga baik pemerintah maupun non-pemerintah. Berdasarkan fakta dilapangan pembagian ketiga kategori tersebut tidak selalu berpisah satu sama lain, karena ada beberapa diantaranya yang berfungsi ganda. Pada saat tertentu seseorang adalah pemilik lahan belum terbangun dan dia merupakan golongan bukan petani (PLO), namun dalam saat bersamaan dia juga berperan sebagai pihak yang menjadi perantara, karena menjabat sebagai pengembang (IA) dan sekaligus juga menggunakan sebagian lahannya untuk kepentingan dirinya sendiri maupun keluarganya (FC).

Dalam analisis ini pola hubungan sosial dalam komunitas lokal sebagaimana yang dikatakan Garna, 1992, bahwa perubahan sosial dapat dilakukan dengan beberapa perluasan, yaitu pada teori evolusi dengan mempertimbangkan perubahan sebagai adaptasi dari suatu sistem sosial terhadap lingkungannya oleh proses diferensiasi internal serta bertambah kompleksnya struktural. Terjadinya, perubahan bentuk masyarakat dari yang sederhana ke yang lebih kompleks, dari yang seragam ke beraneka ragam.

Secara artikulasi, lebih spesifik diarahkan pada proses penyatuan antara budaya lokal dan budaya global dalam posisi yang hirarkis. Globalisasi budaya tidak selalu mengarah ke homogenisasi nilai-nilai budaya dan itensitas masyarakat lokal, karena ada tarikan budaya atau pull of culture dan peminjaman budaya ditandai dengan individu yang aktif, kreatif, dan fleksibel dalam mengonstruksi identitasnya lewat proses projection (pemilahan) dan interjection (pemilihan) terhadap bahan-bahan budaya, sesuai dengan kebutuhan dan kerangka berpikir budayanya yang berbeda-beda. Proses interplay of mediation antara budaya akan dialami secara langsung. Dalam media interplay muncul artikulasi nilai dan norma (Millassoux, C dan Pierre Phillipe Rey, 1972), dengan menjelaskan bahwa keberadaan moda produksi atau sistem ekonomi yang mengada di suatu negara secara bersamaan, tetapi dalam posisi yang hirarkis. Ada dominasi antara moda produksi yang satu terhadap moda produksi yang lain. Unsur budaya lokal dan budaya global mengada bersamaan, sehingga mengondisikan budaya global lebih banyak dijadikan rujukan dibanding budaya lokal. Kondisi ini membawa konsekuensi pada identitas etnis masyarakat lokal yang mengondisikan munculnya identitas baru (fiturfitur baru), masyarakat berubah dan menjelma menjadi masyarakat kosmopolitan.

\subsection{Perubahan sosial}

Pada babakan ini perubahan inovasi yang terdapat di wilayah pengembangan Bandar Udara Internasional Sultan Hasanuddin tidak terjadi secara signifikan yang disebabkan oleh kualitas sumber daya yang dimiliki oleh penduduk lokal belum optimal, sebagaimana yang dikatakan oleh informan Abdul Rahman, bahwasanya penyebab perubahan inovasi tidak terjadi disebabkan oleh keterbatasan sarana dan prasarana yang dimiliki oleh warga masyarakat lokal utamanya faktor pendidikan. Disamping itu pula faktor keterampilan juga memberikan pengaruh, sehingga masyarakat lokal tidak dapat bersaing secara cepat terhadap dampak pengembangan kawasan Bandar Udara Internasional Sultan Hasanuddin.

Selain dari pada itu proses perubahan sosial yang dikondisikan oleh perubahan kondisi lingkungan di Kawasan Bandar Udara Internasional Sultan Hasanuddin terdapat perubahan. Hal ini dapat dilihat dari kondisi lingkungan sosial warga masyarakat yang saat ini telah mengalami perkembangan dengan adanya pengembangan kawasan bandara. Kondisi tersebut yang dimaksud adalah lingkungan warga masyarakat telah dapat diakses dan mengadopsi pola-pola kehidupan kekotaan, diantaranya masyarakat lokal dapat beradaptasi dengan kemajuan yang terdapat di daerah kota yang disebabkan faktor trend yang mereka adopsi dari penduduk pendatang. 
Dampak dari pengembangan kawasan Bandar Udara Internasional Sultan Hasanuddin memberikan dampak bahwa penduduk lokal hampir sebagian besarnya telah mengadopsi trend yang dilakukan oleh penduduk pendatang (warga masyarakat kota). Hal tersebut dapat dilihat dari perkembangan yang terjadi dalam kehidupan warga masyarakat lokal yang cenderung mengalami perubahan. Dimana perubahan yang terjadi diantaranya dalam kehidupan sosial masyarakat yang hampir sebagian besar penduduk lokal telah mengadopsi adat dan budaya utamanya bagi generasi muda yang sudah tidak lagi melestarikan nilai-nilai budaya yang terdapat dalam kehidupan sehariharinya.

Wilayah Peri Urban merupakan wilayah yang dinamis, bahkan dapat dikatakan pada bagian tertentu, khususnya yang berbatasan langsung dengan daerah kekotaan terbangun merupakan wilayah yang paling dinamis dibandingkan dengan bagian-bagian lain. Penyebab utamanya adalah tingginya kekuatan penarik (magnetic forces/full forces/attracting forces) bagian ini baik bagi penduduk maupun fungsi-fungsi kekotaan. Secara umum dapat dikatakan bahwa semakin dengan lahan terbangun, makin kuat daya tarik bagian ini dan sebaliknya makin jauh makin lemah daya tariknya.

Pendatang-pendatang di Wilayah Peri Urban tidak hanya berasal dari bagian yang lebih jauh dari lahan kekotaan terbangun saja, namun banyak juga yang datang dari bagian dalam kota. Sebab-sebab tertentu tersebut merupakan kekuatan-kekuatan penentu penyebab terjadinya mobilitas tempat tinggal (residential mobility) dan mobilitas fungsi-fungsi (functional mobility). Pengertian fungsi dalam hal ini diartikan sebagai kegiatan sehingga functional mobility dapat dipadankan dengan activity mobility. Setiap analisis gerakan spasial horisontal (spatial horizontal movement) jelas tdak hanya menekankan ada daerah tujuan dari gerakan tersebut, namun juga harus memperhatikan daerah asal dari gerakan tersebut yang masing-masing memiliki kekuatankekuatan yang tertentu yang menyebabkan sesuatu gerakan serta menentukan kuat atau lemahnya gerakan yang terjadi. Dalam Wilayah Peri Urban dikenal ada 3 macam kekuatan spasial horisontal utama yang dapat dikategorikan sebagai; (1) kekuatan sentrifugal;
(2) kekuatan sentripetal; dan (3) kekuatan lateral.

Dalam hal ini akan diuraikan secara singkat mengenai ke 3 kekuatan tersebut yang dimulai dari, pertama, kekuatan sentrifugal sangat ditentukan oleh dua macam kekuatan, yaitu apa yang disebut sebagai kekuatan penarik dan kekuatan pendorong (push forces/propelling forces). Dua macam kekuatan ini menjadi kekuatan paling menentukan terhadap intensitas dan kekuatan gerakan yang terjadi. Makin kuat kekuatan pendorong dan penarik, maka makin tinggi pula gerakan dan makin tinggi intensitas gerakan yang timbul. Kekuatan penarik adalah kekuatan yang bersifat menarik penduduk atau fungsi menuju ke arah dimana kekuatan tersebut berada. Kekuatan penarik ini berada ditempat tujuan gerakan (place of destination), sedangkan kekuatan pendorong adalah kekuatan yang memiliki sifat mendorong penduduk dan atau fungsi meninggalkan tempat asal penduduk atau fungsi semula berada, dengan kata lain bahwa ekuatan pendorong adalah kekuatan yang berada di tempat asal gerakan (place of origin) (Yunus, 2008).

Dalam pandangan Lefebvre (1991), ruang senantiasa adalah ruang sosial karena space is a social product. Untuk memahami ruang sebagai produk sosial, pertama-tama penting bagi kita untuk ke luar dari kebiasaan dan pemahaman lama dalam memahami ruang sebagaiman dibayangkan sebagai semacam realitas material yang independen atau pemahaman ruang sebagai swadiri (space in itself). Bertentangan dengan pandangan ruang sebagai swadiri, Lefevbre, 2000 , menggunakan konsep production of space (produksi ruang) yang berisi pemahaman ruang yang secara fundamental terikat pada realitas sosial. Baginya pemahaman ruang sebagai in itself, tidak akan pernah menemukan titik mula epistemologis yang memadai. Ia menegaskan bahwa ruang tidak pernah ada "sebagaimana dirinya", ia diproduksi secara sosial.

Untuk menjelaskan ruang sebagai produk sosial ini, Lefebvre, 2003, mengajukan dimensi triadic dari ruang yang menunjukkan produksi spasial itu yakni; Pertama, praktik spasial. Konsep ini merujuk pada dimensi berbagai praktik dan aktivitas serta relasi sosial. Klasifikiasi spasial menekankan aspek aktivitas yang simultan. Dalam bentuk yang konkret Pratik spasial berisi berbagai jaringan interaksi, komunikasi serta berbagai proses produksi dan pertukaran dalam 
masayarakat yang tumbuh dalam kehidupan sehari-hari. Praktik sosial dalam perspektif Lefebvre, 2002, selalu mengapropriasi ruangruang fisik tempat praktik sosial terjadi atau berlangsung. Apropriasi dapat berupa tindakan fisik dan konkret memberi tindakan atau melalui konstruksi ilmu pengetahuan yang memungkinkan praktik pemaknaan terhadap ruang, yang merupakan sebuah pemfungsian spesifik terhadap ruang (specific use of space).

Lefebvre, 2004, menjelaskan bahwa ruang yang dikonseptualisasi sebagai wacana adalah ruang itu sendiri. Secara terstruktur, ruang dikonseptualisasi menjadi sebuah abstraksi dan ilmu oleh para ilmuwan, seperti arsitek, ahli planologi, insinyur sipil, pemegang kebijakan, pemerintah. Abstraksi secara terus-menerus diwacanakan pada akhirnya menjadikan ruang runtuh ke dalam representasi.

Ruang urban merupakan contoh yang paling tepat. Terminologi "Ruang Urban" itu sendiri merupakan produksi dari praktik intelektual melalui sistem tanda yang verbal, dan terartikulasikan dalam ruang ilmu pengetahuan. Terminologi Ruang Urban hadir sebagai istilah yang merepresentasikan ruang hidup (lived space) manusia kontemporer di perkotaan. Dalam ruang hidup ini, praktik spasial terjadi dan terus-menerus mengapropriasi spasialitas sehari-hari manusia urban. Lebih jauh lagi, spasialitas ini kemudian dipersepsi oleh ilmuwan yang ahli di bidang ruang (sebagai perceived space) dan kemudian secara verbal dipersoalkan dalam berbagai diskusi akademik. Hasil dialog akademis tersebut menghasilkan ruang baru (berupa conceived space), yaitu wacana ilmiah tentang ruang (dari ruang fisik di kota) yang dibicarakan. Dari situlah konsepsi terhadap ruang tertentu hadir dan melembaga sebagai wacana. Dalam situasi ini, gagasan seorang arsitek atau desainer interior tentang ruang tidur yang ia gambar di buku sketsanya sudah merupakan sebuah ruang. Representasi ruang, dalam konteks ini, berfungsi sebagai penata dari berbagai relasi yang menghubungkan ruang-ruang tertentu dengan berbagai wacana di luar ruang itu sendiri. Representasi inilah yang memberikan jalan bagi manusia untuk membingkai ruang pada konteksnya, dan kemudian memaknainya melalui sistem tanda, kode dan bahasa. Pemaknaan ini diperlukan agar ilmu pengetahuan tentang ruang dapat dikembangtumbuhkan, dan dengan demikian manusia dapat menempatkan dirinya sebagai pengendali dari berbagai relasi antar-ruang yang terjadi. Manusia membutuhkan ilmu pengetahuan tentang ruang agar dapat memroyeksikan dirinya dan orang lain dalam sebuah ruang.

Ruang Representasi berisi dimensi simbolik dari ruang. Ruang Representasi menegakkan elemen yang bukan merujuk pada ruang itu sendiri melainkan kepada sesuatu yang lain di luar ruang; kekuatan adikodrati, bahasa, negara, prinsip-prinsip maskulinitas dan feminimitas. Dimensi produksi ruang ini merupakan dimensi imajinatif yang menghubungkan ruang dengan simbol-simbol dan makna seperti monumen, artefak, tugu.

Ruang publik yang seharusnya dalam konsep Habermas menjadi ruang tempat konsensus terbangun karena pertemuan kepentingan dari berbagai kelompok yang (dipaksa menjadi) egalitarian, dalam konsep Lefebvre, 2009, menjadi pisau bermata dua. Di satu sisi hal tersebut dapat terjadi jika kekuasaan yang beroperasi melalui spasialisasi dominan berhasil menemukan logika umum, untuk diterjemahkan ke dalam berbagai wacana kepentingan. Maka menurut Lefebvre, Ruang Representasional hanya menghasilkan hal-hal yang simbolik sifatnya. Menjadi persoalan adalah, karena seringkali produk simbolik Ruang Representasional ini terjebak dalam trend estetik, ia menjadi temporer dan mudah sekali kehilangan momentumnya.

Jika mengacu kepada logika berpikir Marxian dalam mereduksi segala praktik sosial ke dalam abstraksi ekonomi, maka Lefebvre, 2009, justru berusaha menambahkan determinisme Marxian tentang relasi produksi ini kepada konteksnya, yaitu melalui relasi manusia dengan lingkungan alamiah yang menjadi latar belakang sosialnya. Lefebvre menempatkan persoalan praktik rasionalisasi sebagai kecenderungan untuk mereduksi ruang ke dalam abstraksi utilitarian, ketika manusia secara kolektif mulai melakukan aktivitas produksinya dengan kesadaran penuh. Modus produksi membangun relasi ruang-ruang dan kemudian memroduksi ruang baru sesuai dengan kepentingan produksi. Cara ini dilakukan dengan apropriasi. Setiap kelompok masyarakat dan setiap modus produksi yang berlangsung memproduksi ruangnya masing-masing. 
Aktivitas produksi ruang membuat sebuah proses produktif tertanam dalam ruang tersebut. Itu sebabnya, ketika membicarakan ruang, aspek historisitas tidak mungkin dihindari. Historisitas dari ruang, sebagai praktik memroduksi realitas, bentuk dan representasinya tidak dapat sertamerta dianggap sebagai kausalitas yang berimplikasi waktu (baik dalam konsep Gregorian tradisional berupa jam, tanggal, hari, minggu, bulan, dan tahun) yang mewujud dalam peristiwa, atau sekuen.

Karenanya dalam pandangan ini, objektivitas merupakan kekuasaan yang terendap. Dari sisnilah jejak-jejak kekuasaan telah terhapus dan telah terlupakan. Pemahaman kita terhadap teori Laclau and Mouffe, 1985, bahwa kekuasaan dan politik merupakan dua sisi keping mata uang logam yang tidak terpisahkan. Kekuasaan mengacu pada pemroduksian objek-objek seperti "masyarakat" dan "identitas", sementara politik mengacu pada ketergantungan yang selalu ada pada objek-objek tertentu. Dalam penelitiannya Sumandiyar, Adi (2017) dalam penemuan relasi kelompok pengusaha secara subjektif dipahami sebagai hubungan untuk mengembangkan potensi-potensi wilayah melalui investasi saham, pengembangan sektor investasi maupun usaha, hingga pembangunan proyek dan program dari penguasa serta penciptaan iklim usaha. Dengan demikian objektivitas mengacu pada dunia yang keberadaannya dianggap lumrah, dunia yang telah kita "lupakan" namun senantiasa tersusun oleh kekuasaan dan politik.

\section{SIMPULAN DAN SARAN}

Struktur sosial yang berada di kawasan bandara tersebut kini telah berubah akibat dari penguasaan ruang yang diproduksi oleh pengelola bandara. Penguasaan ruang yang terjadi dimanfaatkan oleh oknum-oknum pengelola bandara untuk menjadikan lahan tersebut sebagai lahan keuntungan mereka dengan cara membiarkan warga masyarakat menghgarap lahan dari bandara, namun pada akhirnya oknum pengelola bandara meminta agar hasil yang diperoleh dari pengelolaan lahan juga sebagian diserahkan oleh oknum yang mengatasnamakan bandara. Fenomena tersebut mencerminkan bahwa lahan yang telah dikuasai oleh pengelola bandara telah terjadi praktik kapitalisasi ruang yang mengarah kepada keuntungan dari hasil yang diperoleh oleh warga nasyarakat lokal, sehingga warga masyarakat hanya dijadikan sebagai alat untuk memperoleh keuntungan yang sebesar-besarnya.

Dampak dari pengembangan kawasan Bandar Udara Internasional Sultan Hasanuddin memberikan dampak bahwa penduduk lokal hampir sebagian besarnya telah mengadopsi trend yang dilakukan oleh penduduk pendatang (warga masyarakat kota). Hal tersebut dapat dilihat dari perkembangan yang terjadi dalam kehidupan warga masyarakat lokal yang cenderung mengalami perubahan. Dimana perubahan yang terjadi diantaranya dalam kehidupan sosial masyarakat yang hampir sebagian besar penduduk lokal telah mengadopsi adat dan budaya utamanya bagi generasi muda yang sudah tidak lagi melestarikan nilai-nilai budaya yang terdapat dalam kehidupan sehariharinya.Wilayah Peri Urban merupakan wilayah yang dinamis, bahkan dapat dikatakan pada bagian tertentu, khususnya yang berbatasan langsung dengan daerah kekotaan terbangun merupakan wilayah yang paling dinamis dibandingkan dengan bagian-bagian lain. Penyebab utamanya adalah tingginya kekuatan penarik (magnetic forces/full forces/attracting forces) bagian ini baik bagi penduduk maupun fungsi-fungsi kekotaan. Secara umum dapat dikatakan bahwa semakin dengan lahan terbangun, makin kuat daya tarik bagian ini dan sebaliknya makin jauh makin lemah daya tariknya.

Dengan demikian penguasaan reproduksi ruang tidak hanya berasal dari bagian yang lebih jauh dari lahan kekotaan terbangun saja, namun banyak juga yang datang dari bagian dalam kota. Sebab-sebab tertentu tersebut merupakan kekuatan-kekuatan penentu penyebab terjadinya mobilitas tempat tinggal (residential mobility) dan mobilitas fungsi-fungsi (functional mobility). Pengertian fungsi dalam hal ini diartikan sebagai kegiatan sehingga functional mobility dapat dipadankan dengan activity mobility. Setiap analisis gerakan spasial horisontal (spatial horizontal movement) jelas tidak hanya menekankan ada daerah tujuan dari gerakan tersebut, namun juga harus memperhatikan daerah asal dari gerakan tersebut yang masing-masing memiliki kekuatan tertentu. 
Adi Sumandiyar, Hasruddin Nur. Penguasaan Reproduksi Ruang Di Kawasan Bandar Udara Internasional Sultan Hasanuddin

\section{DAFTAR RUJUKAN}

Castells, Manuel. 1977. The Urban Question: A Marxist Approach. London: Edward Arnold.

Garna, Judistira K. 1992. Teori-teori Perubahan Sosial. Penerbit Program Pascasarjana Universitas Padjajjaran Bandung.

Harvey, David. 1990. The Condition of Postmodernity: An Inqiury into the Origins of Cultural Change. Oxford, Oxford University Press.

Harvey, David. 2003. The New Imperialism. Oxford: Oxford University Press.

Harvey, David.2012. Rebel Cities: From the Right to the City to the Urban Revolution. London: Verso.

Laclau and Mouffe. 1985. Hegemony and Socialist Strategy: Towards a Radical Democratic Politics. Verso.

Lefebvre, Henri. 1991. The Production of Space. Translated by Donald Nicholson-Smith, Oxford: Blackwell.

Lefebvre, Henri. 2000. The Production of Space. Georgetown University Press: New York.

Lefebvre, Henri. 2002. Critique of Everyday Life,. Trans. John Moore, London and New York: Verso.

Lefebvre, Henri. 2003. The Urban Revolution. University of Minneapolis Press: Minneapolis.

Lefebvre, Henri. 2004. Rhythmanalysis: Space, Time and Everyday Life. Continuum: London and New York.

Lefebvre, Henri. 2009. State, Space, World. University of Minnesota Press: Minnesota.
Millassoux, C. dan Pierre Phillipe Rey, 1972. From Reproduction to Production. Economic and Society.

Sumandiyar, Adi. 2017. The Relation between Business and Authority: Maros Political Atmospheric Study in Indonesia. Mediterranean Journal of Social Sciences 8(4-1):165172https://www.researchgate.net/pub lication/326103989_The Relation_b etween_Business_and_Authority_M aros_Political_Atmospheric_Study_i n_Indonesia.

Yunus, Hadi Sabari. 2008. Dinamika Wilayah Peri Urban (Determinan Masa Depak Kota). Yogyakarta: Pustaka Pelajar. 